\title{
QPCT wt Allele
}

National Cancer Institute

\section{Source}

National Cancer Institute. QPCT wt Allele. NCI Thesaurus. Code C102505.

Human QPCT wild-type allele is located in the vicinity of 2 p22.2 and is approximately 29

$\mathrm{kb}$ in length. This allele, which encodes glutaminyl-peptide cyclotransferase protein, plays a role in the post-translational protein modification. 